\title{
À luz da contradição: projetos neocolonialistas na oposição ao Estado Novo Português
}

\author{
Franco Santos Alves da Silva*
}

\begin{abstract}
Resumo: O colonialismo do Estado Novo português foi um dos pilares que sustentavam o discurso da grandeza do império ultramarino, e da suposta facilidade com que Portugal estabelecia e mantinha contatos com outras culturas. Entretanto, no contexto do final da década de 1950 e início de 1960, o mundo não via com bons olhos a posse de colônias na África, como também do surgimento de diversos movimentos de resistência em Angola e Moçambique, a oposição passou a enfatizar o apoio a estes movimentos, além de denunciar os abusos cometidos em território africano, para, desta forma, buscar o próprio fim do regime.

Nas páginas do jornal Portugal Livre, editado no Brasil, surgiram algumas propostas para a "questão colonial", aonde traçavam projetos políticos de emancipação para as colônias. Escrito pelo capitão Henrique Galvão e pelo general Humberto Delgado, ambos antigos defensores do sistema colonial e dissidentes do regime, as propostas eram permeadas por um discurso neocolonialista que ajudou a aumentar o abismo existente na oposição e expor que a mentalidade colonial estava mais presente na oposição, e na própria cultura portuguesa, do que eles mesmo supunham.

Palavras-chave: colonialismo, exílio, Estado Novo português.
\end{abstract}

Abstract: The colonialism in Portuguese "Estado Novo" was one of the pillars that supported the discourse of greatness overseas empire, and the supposed ease with which Portugal established and maintained contacts with other cultures. However, in the context of the late 1950s and early 1960s, the world did not see kindly on the possession of colonies in Africa, as well as the emergence of various resistance movements in Angola and Mozambique, the opposition began to emphasize support these movements, and report abuses committed on African soil, for thus seeking the very end of the regime. In the pages of the newspaper "Portugal Livre", edited in Brazil, there have been some proposals for the "colonial question" where political projects of emancipation traced to the colonies. Written by Captain Henrique Galvão and general Humberto Delgado, both former supporters of the colonial system and dissidents of the regime, the proposals were permeated by a colonialist discourse which helped to increase the gap in the opposition and expose the colonial mentality was more present in opposition, and even in the Portuguese culture, than they even assumed.

Keywords: colonialism, exile, the Portuguese Estado Novo.

O presente artigo tem como objetivo analisar o conteúdo e a repercussão de três projetos de oposicionistas para a independência das colônias portuguesas na África. As propostas surgiram entre os anos de 1959 e 1961 no jornal Portugal Livre, editado no Brasil por portugueses exilados, sob a autoria do capitão Henrique Galvão e do general Humberto Delgado, ambos militares dissidentes do Estado Novo de António Oliveira Salazar.

\footnotetext{
* Mestre em História Contemporânea pela Faculdade de Letras da Universidade do Porto, Portugal. Bacharel em História pela Universidade Federal de Santa Catarina.
} 
Portugal foi palco do mais longo regime autoritário da Europa Ocidental no século XX, isso se tomarmos o período da Ditadura Militar, entre 1926 e 1928, a Ditadura Nacional, entre 1928 e 1933 e o Estado Novo, iniciado em 1933 e findado em abril de 1974, com a Revolução dos Cravos. Durante este período o país manteve suas colônias no continente Africano, como em Moçambique, Angola, Guiné, os arquipélagos São Tomé e Príncipe e Cabo Verde, além de Goa, na Índia, através de uma reordenação do seu discurso de legitimação da presença portuguesa em África, como previsto no Ato Colonial de 1930. Não obstante, durante este mesmo período o país foi alvo de inúmeros protestos, pressões internacionais e opositores que pediam a queda regime e o fim do colonialismo no continente africano

Diversas questões pertinentes a este tema permeavam a oposição ao Estado Novo português: derrubar primeiramente o regime, e tornar as colônias livres? Exigir a queda, com o apoio dos africanos? O que fazer com as colônias? Perguntas tais que geravam uma série de discussões e argumentação, pois mexiam de maneira profunda com a mentalidade portuguesa, amplamente forjada pelo regime, na intenção de criar uma identidade unitária entre Portugal e suas colônias. Portanto, separar estas colônias, poderia significar separar o próprio país.

Inicialmente é necessário frisar alguns conceitos sobre colonialismo e neocolonialismo utilizados neste artigo, bem como encontrado na documentação utilizada para escrevê-lo. Segundo Lopes sobre isto

surgem expressões como colonialismo tardio ou do século XIX. Enquanto o neocolonialismo passa a ser identificado com os processos decorrentes das atividades econômicas internacionais e dos acordos bilaterais que interferem na autonomia dos recém Estados independentes da África. (Lopes, 2011:12).

Entretanto pensamos que o caso de Portugal pode ser um pouco diferente das nações europeias envolvidas no contexto do século XIX, isto por que Portugal já mantinha suas colônias desde o século XVI, e, assim reviu - e alterou - seus interesses no continente africano sem perder a posse do mesmo. Deste modo torna-se mais complexo, e mesmo inviável, uma classificação única para as colônias, ou ainda, para o colonialismo português. Se o termo "neo" remete aos interesses do capital imperialista entre os anos de 1875 e 1914, sobretudo à luz da argumentação encontrada nas fontes primárias, "neo" ganha um novo sentido. Veremos que o prefixo "neo", nos artigos e contextos dos oposicionistas, pode 
expressar, literalmente e como o próprio significado, "novo", ou seja, colonizar novamente, ou um "colonialismo disfarçado" e repaginado.

\section{O Contexto}

Ainda que lentamente e em diferentes momentos na sua ascensão à Presidência do Conselho, Salazar criou uma série de medidas que visavam à centralização dos poderes. De modo muito sucinto, tais medidas iniciaram ainda no período da Ditadura Militar com a abolição dos partidos políticos e a criação do partido único, a União Nacional. Em janeiro de 1930 assumiu a pasta das Colônias e, entre outras medidas, sancionou o Ato Colonial que visava da parte interna, refrear as revoltas no ultramar português, e externa, conter a pressão internacional que vinha considerando ilegal o trabalho forçado. As "províncias ultramarinas" passariam a ser chamadas de "colônias", com um aumento de sua subordinação a Lisboa, o Ato era extremamente nacionalista e não punha em questão a legitimidade da posse das colônias por parte de Portugal. (Menezes, 2010:119).

Logo após a revisão constitucional nos anos 30 sob a pasta do ministro das colônias Armindo Monteiro "passou-se a considerar as colônias portuguesas como províncias ultramarinas, abolindo-se a designação de "império colonial português" - era a adoção de uma política colonial integralista em substituição do esquema colonial clássico". Assim, como indicado anteriormente, muda-se os nomes, sem alterar a pose em si, haja vista que "Portugal não possuía, sob sua tutela, quaisquer colônias, mas sim províncias ultramarinas, que como as províncias do território continental europeu, não aceita discutir.”. (Oliveira, 1992:71)

O processo de sacralização do império português foi facilitado pela continuo relacionamento da questão colonial com a identidade do país, o que acabou por influenciar - e mesmo enfraquecer - algumas correntes oposicionistas e anticolonialistas. (Cf. Valentim, 1995:51). Trabalho realizado, em grande parte, por Antônio Ferro, no Secretariado da Propaganda Nacional (SPN). Como exemplo está a comemoração do duplo centenário, da fundação da nacionalidade e da reconquista de independência nacional, em 1940, integrado com a agenda da grande Exposição do Mundo Português. Iniciada sob as muralhas do Castelo de Guimarães com o lema "Oito séculos de independência nacional" e continuado em junho do mesmo ano no Porto, com uma grande exposição mostrando as riquezas do império. Havia a pretensão de mostrar ao mundo, perante a crise europeia e a II Guerra Mundial, a grandeza do império português com seu suposto nacionalismo não agressivo, moral e ético e ainda 
divulgar as realizações do Estado Novo (Oliveira, 1992:55). É importante ressaltar que este mesmo secretariado foi responsável pela divulgação do lema "Deus, Pátria e Família", doutrina baseada na moral cristã e difundida por organizações juvenis, como a Mocidade Portuguesa, e paramilitares como a Legião Portuguesa, assim como na educação fortemente ideológica e nacionalista.

Entretanto o regime criou seus próprios e futuros opositores, pois, ao mesmo tempo em que esta ideologia forjou e influenciou uma enormidade de pessoas que trabalhavam para o próprio governo, também criou condições ideais para o surgimento de teóricos e propensos conhecedores das questões coloniais. Isto por que Portugal necessitava de um grande aparato para gerir suas colônias, desde ministros, militares, comissários e secretários. Entre estes podem se destacar Norton de Matos, em um primeiro momento, e Henrique Galvão e Humberto Delgado, numa etapa mais tardia da oposição ao Estado Novo.

Tanto a ideia de uma "nação una" ou o projeto do "Portugal maior", como a mentalidade baseada na "função histórica da Nação Portuguesa" eram conceitos divulgados entre os dois republicanos Armindo Monteiro e Norton de Matos, este último viria a se tornar candidato da oposição na eleição de 1949, enquanto que Monteiro, ex-ministro das colônias entre 1931 e 1935 . Neste contexto produziram uma série de relatórios, ensaios e memórias que revelam o pensamento central do regime acerca das colônias africanas.

\begin{abstract}
O que mais ressalta nestes textos, e em muitos outros da mesma época, é o seu nacionalismo exacerbado, de índole quase religiosa, e o misticismo imperial que o acompanha: a crença e a visão de um futuro de grandeza e harmonia que resgataria todas as dificuldades, todas as misérias do presente. No fundo, estamos ainda perante o "o mito do Eldorado", mas numa nova versão, onde os interesses econômicos, embora presentes, cedem lugar central a preocupações de ordem política, consubstanciados na "grandeza da nação". (Valentim, 1995:46).
\end{abstract}

Pode-se afirmar que o caso de Norton de Matos, alto comissário em Angola, ministro na I República e Grão-Mestre da Maçonaria portuguesa, é um pouco diferente, e mais diretamente aos exemplos a serem analisados neste artigo. Isto porque, dissidente do regime, empenhou-se na campanha para presidência da república, realizada entre 1948 e inicio de 1949, quando desistiu da candidatura por falta de condições de continuar a campanha, mas acabou por reanimar a oposição. Mesmo com a desistência, o candidato viajou do norte ao sul do país, fazendo grandes comícios em Lisboa e no Porto. Utilizando da vaga aberta pelo próprio regime, o general Norton de Matos usou das táticas já utilizadas em 1945 e que viriam 
a ser utilizadas até o final do Estado Novo: denúncia de falhas e erros do regime e tentativa de instigar nos militares um movimento de revolta (Oliveira, 1992:), mas sem tocar nas questões das colônias portuguesas, pois neste momento, não era interessante para a oposição questionar e contestar a possessões ultramarinas de Portugal. Esta questão viria a mudar com o que pode se chamar uma nova geração de opositores portugueses, sobretudo situadas no exílio.

\section{O exílio brasileiro e os jornais de oposição}

A candidatura do general Humberto Delgado em 1958 pode ser considerada o ponto inicial para as mudanças que a oposição viria a ter no exílio, haja vista que a concessão de asilo político por parte do governo brasileiro e sua consequente vinda para o Brasil causaram furor e ânimo à comunidade de portugueses exilados, e acabaram por criar uma onda de esperança e expectativa no grupo. Contudo, logo esse ânimo se dissiparia com as opiniões políticas e tomadas de decisões de Delgado sobre como deveria se reorganizar a oposição ao Estado Novo a partir do Brasil. O general trouxe consigo a sigla do Movimento Nacional Independente (MNI) e lançou uma diretiva que nomeava pessoas conforme sua vontade. Fez ainda críticas diretas ao núcleo de oposicionistas situados em São Paulo, sobretudo organizados no jornal Portugal Democrático, afirmou também que esse era um núcleo de comunistas, o que contrariava a opção de ver Portugal livre de fato. Em meio a tal contexto, alguns exilados, descontentes com a linha editorial do Portugal Democrático, procuraram Delgado e fundaram o jornal Portugal Livre.

A década de 1950, o Brasil foi palco de encontro de duas gerações de exilados, distintas na idade e experiência histórica e, principalmente, formação ideológica. O grupo com o qual Heloisa Paulo vem pesquisando trata-se de uma primeira geração, que viu, e muitas vezes participou, da instauração da República e fez oposição à Ditadura na década de 1930, antes mesmo da instauração do Estado Novo. Essa geração tem formação mais conservadora, composta ainda por monárquicos e republicanos, que tem em Jaime Cortesão e Sarmento Pimentel dois exemplos. Já a segunda geração, da qual tratam autores como Fábio Ruela e Douglas Mansur, é composta por exilados que nasceram, ou cresceram, dentro do regime, e participaram das instituições paramilitares de caráter fascista, como a Mocidade Portuguesa e Legião Portuguesa, na segunda metade da década de 30. Houve, então, um confronto de mentalidades e divergências políticas, cuja compreensão dessas diferenças ideológicas pode resultar em uma interpretação mais rica e dinâmica sobre os debates que a 
oposição travou a partir do exílio, sobretudo nas questões relacionadas às colônias e travadas a partir do periódico Portugal Livre.

O jornal Portugal Livre teve vida efêmera, foram apenas dezesseis edições, entre novembro de 1959 e março de 1961. Pode ser considerado pouco se comparado ao jornal Portugal Democrático, igualmente publicado no Brasil, com duração de dezessete anos e mais de duzentas edições; no entanto, isso não diminui sua importância para a História, principalmente porque ele foi fundado em meio às divergências políticas entre o grupo de portugueses exilados em território brasileiro. O jornal contou com a colaboração de Humberto Delgado, Henrique Galvão, Victor da Cunha Rego, Miguel Urbano Rodrigues, João Santana Mota, João Alves das Neves, Joaquim Ribeiro Bastos Paulo de Castro, Pedroso Lima ${ }^{1}$ e o brasileiro Claudio Abramo, como diretor, mesmo cargo que exercia a frente do jornal $O$ Estado de S. Paulo².

O jornal funcionava como uma espécie de caixa de ressonância, pois republicava matérias de outros jornais cujo acesso não era tão fácil, tais como os periódicos ingleses Evening Standard ou Daily Mail, como na ocasião da cobertura da visita de Humberto Delgado à Europa, ou o brasileiro como O Estado de S. Paulo, cuja redação era repleta de portugueses. A manobra tinha algumas importantes funções, como divulgar a opinião internacional a propósito do regime dentro do território português e cobrir eventuais furos na diagramação que a pressa da redação exigia. O que acabou por solidificar o laço com jornalistas estrangeiros que simpatizavam com a causa dos anti-salazaristas, como era o caso dos colaboradores Basil Davidson e Marvin Harris.

Basil Davidson era colaborador do O Estado de S. Paulo e colunista do semanário de esquerda inglês The New Statesman, jornal que deu amplo apoio à fuga de Galvão e à viagem de Delgado, e estava sendo processado por Salazar. A sua relação com o Portugal Livre deuse com a publicação de um artigo de sua autoria e o envio de uma carta, pelo jornalista inglês, saudando o jornal pela sua atitude de reeditar seu texto e, principalmente na posição anticolonialista assumida pela redação (Davison, 1960:4).

\footnotetext{
${ }^{1} \mathrm{O}$ número e nomes de portugueses colaboradores podem variar. Outro ponto importante é a contribuição por parte dos intelectuais brasileiros no jornal.

${ }^{2}$ Em 1957, uma leva de jornalistas portugueses, provenientes do jornal português Diário Ilustrado, veio para trabalhar no jornal $O$ Estado de S. Paulo a convite de Vítor Ramos e Manuel Ferreira Moura; Dentre eles, Miguel Urbano Rodrigues, Victor da Cunha Rego e João Alves das Neves. Estavam descontentes com a linha imposta no editorial do jornal e suspeitava de infiltração da polícia política, a PIDE (Polícia Internacional e de Defesa do Estado).
} 
Outro importante colaborador internacional foi Marvin Harris, antropologista da Universidade de Columbia, que escreveu um trabalho sobre Moçambique $A$ first hand report on Labor and Education in Mozambique, que escreveu quando visitou o continente africano. Seus artigos, claros e didáticos, eram direcionados para todos os leitores e não somente para portugueses e oposicionistas (Harris, 1959:5). Obviamente que o jornal era aberto a todos, inclusive brasileiros, mas o texto de Harris esclarecia dúvidas sobre diversas questões das colônias portuguesas, fugindo dos jargões de textos fervorosos contra os horrores do Estado Novo ou à favor da liberdade. Foi de sua autoria um longo dossiê sobre a presença portuguesa na África, intitulado Portugals African Wards (africanos tutelados em Portugal), que passou por detalhes bem específicos sobre a condição social do nativo até os problemas enfrentados pela negligência do sistema colonial. $\mathrm{O}$ texto discute os mecanismos de regulamentação do nativo, por intermédio do "regulamento dos serviçais indígenas" e outros meios de coerção e controle, como o estatuto de cidadania para os africanos, buscando sempre separar o que dizia a lei e o que ocorria efetivamente na prática (Harris, 1960:2).

\section{Galvão e Delgado: figuras controversas}

O general Humberto Delgado era um homem do regime, anticomunista, apoiou tanto no golpe militar, quanto na instauração do Estado Novo. Foi condecorado e representava Portugal em diversas questões internacionais. Quando morou por cinco anos nos Estados Unidos da América, como adido militar da Embaixada Portuguesa e membro militar da OTAN (Organização do Tratado do Atlântico Norte), nesta ocasião tomou conhecimento da democracia americana, e sua visão a propósito do salazarismo começou a mudar, até ser convidado pela oposição para ser candidato à presidência da república. A partir da década de 1940, estabeleceu uma série de contatos com instituições democráticas, por intermédio de negociações com os ingleses entre 1941 e 1943; foi ainda representante português na Organização Internacional da Aeronáutica Civil (1947-1950), em Montreal, e depois de 1952 a 1957, chefe da Missão Portuguesa na OTAN (Raby,1988:179).Essa “descoberta” por si só não despertou repentinamente o interesse pela democracia, mas sim se misturou a um espírito inquieto e predisposto para aceitar as transformações. Agrega-se a isso uma forte anglofilia de Delgado; como exemplo, o caso da base dos Açores em 1941-1943. (Ibidem).

Humberto Delgado teve sua formação ideológica forjada dentro dos quadros militares do Estado Novo, como todos de sua geração. Seu rompimento com o regime, e sua "tomada 
de consciência" sobre o funcionamento da democracia, sobretudo a americana, não resultaram em uma visão progressista do mundo. Assim, seu comportamento e relação com os demais eram sempre pautados por uma concepção autoritária do trabalho político (Rodrigues, 2002:158).

Henrique Carlos Malta Galvão foi organizador da Exposição Colonial realizada no Porto em 1934, apologético do colonialismo português e, principalmente, defensor do exército, como representante da "Alma Nacional". Em 1936, já havia publicado vinte e um livros passando por áreas técnicas, relatos de viagens, história, teatro, romance e poesia. Por ironia, sua ruptura com o Estado Novo foi justamente sobre a questão colonial, ponto que o capitão defendia arduamente, ainda que com um conceito idealista sobre o assunto. Em 1948, depôs como testemunha de defesa para seu amigo, o coronel Carlos Selvagem, que havia tentando um Golpe Militar no ano anterior. Enquanto no ano seguinte, nas eleições de 1949, demonstrou comportamento ambíguo na candidatura de Norton de Matos e apresentou na Assembleia Nacional um projeto sobre o "aviso-prévio para o trabalho forçado em Angola". Os projetos idealistas e reformistas de Galvão pretendiam o desenvolvimento econômico e maior integração entre as colônias.

Galvão criticou a mudança do termo "províncias ultramarinas" para "colônias", um conceito historicamente condenando que acabaria por manchar a imagem de Portugal na ONU, e achou que seria possível a criação de projeto "República-Federal Euro-Africana" para prolongar a influência portuguesa na África, em vez de o país perder tudo gradualmente (Rodrigues, 2002:175). Ficaria então caracterizado novamente pelo excesso de denúncias em público a respeito dos problemas nas colônias, sobretudo com intervenções na Assembleia Nacional, quando representava Angola, na tentativa de corrigir os abusos laborais e, da mesma maneira, na defesa de conspiradores militares de 1947 (Meneses, 202:453).

\section{Os Projetos}

Se pensarmos os assuntos tratados pelo jornal, ao longo de sua curta existência, em forma de blocos, é possível considerar que o colonialismo, e demais temas ligados a ele, foi o mais abordado, e também um dos mais polêmicos. $\mathrm{O}$ mundo estava, aos poucos, condenando às velhas nações colonialistas, e o jornal percebeu, assim como já vinha fazendo o Portugal Democrático, que denunciar os abusos e problemas ocorridos na África ajudaria a dar sobrevida às lutas oposicionistas com o apoio de nações estrangeiras. Esse fator continuou 
mesmo depois do fechamento do Portugal Livre, porque durante a ditadura militar brasileira o Portugal Democrático foi o único jornal que falou abertamente de luta de classes sem ser fechado pela censura. Visto que os militares não queriam ir contra um jornal assumidamente anticolonialista, à frente de toda a comunidade internacional e em plena guerra colonial ocorrendo na África. Mas, mesmo sendo o assunto mais discutido, não significa que as opiniões estivessem em uníssono; pelo contrário, foi um dos fatores que ajudou a transformar em abismo os rachas já existentes entre a oposição.

Enquanto a Guerra Fria deu sobrevida ao regime, a independência das colônias britânicas e holandesas pôs um grande dilema para o Estado Novo. Os sentimentos independentistas e anticolonialistas, que afloraram com o término da Segunda Guerra Mundial, se devem a três fatores: a Carta do Atlântico, firmada entre EUA e a Grã-Bretanha, que previa a independência e direto à autoafirmação de todos os povos e universalidade dos princípios da democracia e liberdade; aos apelos e pressão de dirigentes das potências aliadas, como o general De Gaulle da França; e por último, a participação dos povos nativos nas colônias e os militares que serviam nas tropas aliadas.

Dimensão central do nacionalismo do Estado Novo, a sobrevivência nas colônias foi a variável mais importante da política externa da ditadura. À medida que a cena internacional se tornou progressivamente desfavorável, o colonialismo transformou-se "gradualmente na quinta-essência do regime" $e$ "substituiu-se ao corporativismo" no núcleo ideológico central do regime (Pinto, 2007:27).

Havia a percepção e necessidade de uma grande transformação na estrutura do país, desde a valorização do negro, ao incentivo à ciência. Contudo, a mudança no sistema colonialista só viria com uma revolução nos hábitos econômicos e sociais, uma vez que os demais países caminhavam para reconhecer a igualdade perante os países africanos, com exceção de Portugal de Salazar, que, segundo Harris, era "o guri com espingarda na mão". (Harris, 1959:7).

A Carta do Atlântico entre F. D. Roosevelt e W. Churchill, definiu os princípios da liberdade, democracia, respeito pelos direitos humanos, direito dos povos à independência e ao autogoverno em agosto de 1941. (Oliveira,1992:57).

Estas medidas acabariam por complicar ainda mais o colonialismo de Salazar, frente à comunidade internacional, portanto havia pressões de todos os lados. Alguma decisão deveria 
ser tomada, bem como traçar o destino dos países africanos, mas, apesar de muita discussão e denúncias, a oposição não se arriscava em um plano definido.

Como apontamos, desde as primeiras edições, a redação do Portugal Livre posicionava-se contra o colonialismo, seja por meio de dossiês sobre a precariedade da vida em Angola e Moçambique, seja denunciando o trabalho forçado e o massacre dos nativos. Os textos diziam compreender e respeitar tal luta, pois também era a mesma dos portugueses, mesmo reconhecendo que não seria fácil vencer a batalha. Contudo, o discurso era recheado de culpas e afirmava que o colonialismo não representava todos portugueses, e havia uma vontade de preservar os laços morais e manter amizade com os povos africanos, opiniões que nem sempre eram consonantes com a visão do editorial, o que acabou por aumentar ainda mais as diferenças no jornal. Entre os integrantes com visão neocolonialista, destacam-se Tomás Ribeiro Colaço, Henrique Galvão e, em menor escala, Humberto Delgado.

De acordo com o artigo “O M.P.L.A., Angola e nós”, na décima primeira edição do Portugal Livre, os democratas apoiavam a causa patriótica e nacionalista do Movimento Popular de Libertação de Angola (MPLA) contra o Estado Novo, mas repudiavam o extremismo quando estes dirigem o ódio a todos os portugueses e condenam a presença portuguesa em África. Segundo Miguel Urbano Rodrigues, a redação mantinha boas relações com o MPLA e com o Partido Africano para a Independência da Guine e Cabo Verde (PAIGCV), e havia uma efervescente troca de comunicados e documentos políticos entre ambos (Rodrigues, 2002:192).

No jantar para a comemoração do 50 Aniversário da Revolução de outubro de 1910, realizado em São Paulo no ano de 1959, Humberto Delgado apresentou uma visão colonialista sob o título "Movimento Nacional Independente - Plano Colonial da Oposição". Tratava-se de uma proposta para resolver a questão colonial, enviada para o presidente Kennedy, dos EUA, a Mac-Millan e ao secretário geral das Nações Unidas, o sueco Dag Hammarskjöld (Delgado, 1998:188). O plano estava dividido em dezesseis tópicos que expunham a visão de Delgado sobre o colonialismo; possuía também uma nova proposta neocolonialista baseada em estados federados. Com um discurso agressivo e conservador acerca dos africanos, o general defendeu a criação de uma Federação de Estados Portugueses, que incluiria as colônias, projeto que em muito se assemelhava com projeto de Jorge de Sena, esboçado no Portugal Democrático. 
Logo após o evento do Santa Maria ${ }^{3}$, Humberto Delgado mudou sua posição quanto à questão colonial, passando a condenar veementemente o colonialismo português e a defender a autodeterminação dos povos. Segundo Rodrigues, o general "teve de vencer a resistência de sua formação de militar e conservadora" para não ficar em descrédito entre seus companheiros, como aconteceu com Galvão (Rodrigues, 2002:159). Em decorrência disso, a redação preparou uma nota de reparação, e o esclarecimento recebeu um contorno gráfico na edição de aniversário do jornal, acompanhado das respectivas assinaturas: "Pelo "Portugal Livre": Francisco Vidal, José Pedroso de Lima, José Santana Mota, Miguel Urbano Rodrigues, Victor da Cunha Rego". Na nota "Esclarecimento sobre a questão colonial”, na décima terceira edição do jornal

Em uma nota intitulada "Esclarecimento sobre a questão colonial", assinada em nome de toda a redação, na décima terceira edição do jornal, afirmavam não haver somente um ponto de vista sobre o assunto, e tampouco um que prevalecesse sobre os demais; portanto, a ideia de Delgado não representava a unidade. Meses depois, foi a vez de Henrique Galvão protagonizar um episódio semelhante, cujo impacto seria maior do que a declaração de Delgado. É interessante salientarmos que a própria trajetória do capitão esteve sempre conectada com as questões coloniais, seja sua obra literária, sua opinião política, os projetos na assembleia, passando pelo próprio contexto de ruptura com o Estado Novo.

Em entrevista exclusiva e polêmica para o Portugal Livre, Henrique Galvão dividiu opiniões e iniciou uma nova fase na organização da oposição no exílio e no próprio jornal, ao expor sua opinião sobre a solução para as colônias portuguesas no ultramar, iniciando por conceituar a sua visão da África, do que ele considera ser a verdadeira, complexa e desconhecida imagem dos países africanos em comparação com a visão tradicional, imposta por políticas imperialistas ambiciosas, religiões e forjada pela literatura (Galvão, 1969:5).

Portugal, pelo seu histórico de quatro séculos na África, conhece seus problemas, e, segundo o capitão, tinha uma missão naquele continente, que foi interrompida pela ditadura de Salazar. O plano previa a emancipação gradual mediante um projeto político e social semelhante ao ocorrido no Brasil, para preservar os laços de fraternidade e o próprio

\footnotetext{
${ }^{3}$ O assalto ao transatlântico Santa Maria ocorreu em 22 de janeiro de 1961, sob o comando do DRIL (Diretório Revolucionário Ibérico de Libertação) com integrantes espanhóis e portugueses, lutando contra a os regimes de Franco e Salazar. A intenção era navegar até Angola e á partir de lá organizar uma revolta que culminaria na derrubada do governo de Salazar. Um tripulante morreu e outro ficou gravemente ferido, em razão disto e da falta de combustível o plano não deu certo e o navio foi escoltado por caças norte-americanos e foi recebido em Recife em 3 de fevereiro daquele ano, aonde o recém presidente empossado Jânio Quadros concedeu asilo político para os integrantes. Apesar do malogro da operação, a ação foi um indicativo da não aprovação do Estado Novo por outros países, no caso EUA e Brasil.
} 
sentimento "de ser português" das colônias africanas. Dessa forma, havia sinais positivos na relação com os países africanos, pois, se não fosse por Portugal, a África sucumbiria aos "elementos destrutivos" já existentes no local, como "a escravatura dos chefes indígenas, as guerras tribais, a feitiçaria e o canibalismo". E é, pois, do próprio colonialismo que emergem esses sentimentos de emancipação. A solução seria uma comunidade, federação ou confederação de estados de língua portuguesa, dado que seria a forma mais natural e humana para realizar-se a emancipação, que só seria possível após a queda de Salazar e do Estado Novo (Idem: 6).

Galvão responde que a emancipação total e radical é irresponsável e inviável, e faz parte de teóricos e "teorizantes" que desconhecem a configuração política tribal e local, pois, caso levada a cabo, agravaria o sofrimento com uma sangrenta guerra civil, o regresso à barbárie e chacina de outras tribos ou, ainda a absorção imediata a outro julgo imperialista, por potência com interesses na África.

Encontram fórmulas tão capciosas quanto as de Salazar para justificarem a permanência dos portugueses - como senhores - no solo africano. Lamentavelmente errado estes democratas, uns iludidos pelos séculos de propaganda dos nossos feitos coloniais, outros por inconfessáveis desejos de domínio da futura II República em territórios alheios, defendem sim a libertação das colônias, mas apenas quando os povos seus naturais, os donos da terra, tenham adquirido consciência política que lhes permita governarem-se a si próprios (Vidal, 1961:1).

De acordo com o autor, não se trata de uma reedição do colonialismo de Salazar, e sim algo novo, moderno e humano. O conhecimento de causa de Portugal, além de qualificálo para a função, o obriga, pois teria uma vocação para a convivência pacífica com povos de outras raças. No fim, Galvão deixa claro que esse é um pensamento seu, mas acredita ser de toda oposição democrática.

Além da entrevista, o problema se agravou ainda mais com a visita de Galvão a União Estadual dos Estudantes (UEE), de São Paulo, em uma sala repleta com jovens estudantes que acompanhavam a guerra colonial. Contudo, Galvão decepcionou, pois defendeu a mesma saída neocolonial para Angola "um projeto de uma futura comunidade de estados LusoAfricanos com a capital em Nova Lisboa (Huambo)”. Assim, pressionado pela série de perguntas dos estudantes, acabou por soltar declarações que expunham seu pensamento colonialista e racista, falou de raças, da presença portuguesa, de tribos e da incapacidade dos africanos de se autogovernarem. Urbano Rodrigues teve de inventar uma desculpa, dizendo 
que Henrique Galvão precisaria descansar e não poderia mais responder perguntas. Com a saída do capitão, Rodrigues tentou consertar as declarações, mas não obteve êxito (Rodrigues, 2002:220).

Como informado anteriormente, estas ideias não haviam sido cunhadas enquanto Henrique Galvão era opositor ao regime, e sim quando foi um dos maiores divulgadores da sua ideologia. A produção textual sobre o tema é abundante, sobretudo baseada na sua experiência administrativa em Angola, e, portanto os textos aparecem com forte olhar de distanciamento sobre o outro, comuns na tradição literária de relatos de viajantes. Dois romances de Galvão podem ser considerados como parte fundamental para a criação da mentalidade colonialista portuguesa, $O$ velo d`oiro, de 1933 e $O$ sol dos tópicos, de 1936. Onde o projeto do Estado Novo é claramente definido dentro da função missionária e imperial d a nação, através da sobreposição cultural de Portugal sobre os países africanos, no que tange aos valores morais, éticos e religiosos.

Nesse corpus ideológico, Nação e Império eram apresentados como
intercambiáveis. Os portugueses reforçavam a sua missão auto-atribuída de
povo colonizador, desbravador e intrépido, com vocação missionária,
portador da Fé e da Civilização a todos os recantos do Império. Estas
idéias, explícitas ou implícitas, encontravam-se, em variados graus e em
diferentes intensidades nos escritos de Galvão, sendo os romances a
expressão dessas ideias. (Zilhão, 2006:87)

A mentalidade expressa por Galvão neste projeto não foi muito distante da esboçada no livro Antropófagos, escrito em 1947, no qual o autor reforça o secular estigma relacionado às práticas de canibalismo africano, ao relatar uma suposta experiência, através de uma narrativa com discurso científico. A própria capa da obra já apresenta uma visão calcada no pré-conceito quanto aos rituais das tribos africanas: a pintura de um homem negro com a boca apresenta-se escancarada, cujo os dentes aparecem afiados ou ausente, em uma alusão animalesca ao título da obra. Segundo Oliva,

Assim, ainda mais que nas décadas anteriores, os "nativos" / "indígenas" que possuíssem alguma intenção de superar seus "atrasos" deveriam aceitar a presença portuguesa e copiar seus modos de viver. O modelo de vestir, a arquitetura das cidades, a estrutura de educação formalizada, a religião cristã, a língua portuguesa e a ideologia do trabalho deveriam ser adotados por todos aqueles que quisessem ascender algum tipo de direito na sociedade colonial (Oliva, 2009:40). 
A tentativa de transformar o nativo africano em cidadão luso "autêntico" através de afirmações de igualdade e da não existência de racismo e violência foi mais um dos ingredientes para fomentar o mito sobre os africanos no imaginário português. Desta forma, o culto aos deuses, as danças, os rituais não compreendidos, como o wudu e o canibalismo (embora tivessem sido a base de textos com caráter antropológico) aparecem como práticas para serem suprimidas.

\section{Conclusão}

Podemos perceber que a chamada "questão colonial" foi enxergada por parte da oposição ao Estado Novo como um dos pontos fracos do regime, o campo internacional foi um grande indicativo neste sentido, onde nações como França, Estados Unidos da América e o próprio Brasil, não viam mais com os mesmos olhos de benevolência e conivência a posse de colônias africanas por países europeus. Neste contexto os jornais opositores situados fora de Portugal, ou seja, no exílio, como o Portugal Livre e o Portugal Democrático, possuíam a liberdade necessária para falar livremente de assuntos os quais em sua terra natal eram proibidos pela coerção da censura e da polícia política. Impulsionados pelo surgimento de novos atores, figuras importantes e dissidentes do próprio regime, como o capitão Henrique Galvão e o general Humberto Delgado, os debates ganharam nova atenção - e mesmo questões e reposicionamentos na forma de agir foram tomados. Estas novas personagens, Galvão atuando na Venezuela à frente do DRIL, e Delgado no Brasil, à frente do MNI, acabaram por polemizar em diversos assuntos, e principalmente no modo de personalista de conduzir os exilados, o que acabou expondo rachas já existentes n própria oposição. As opiniões de ambos passaram a ser vista nestes periódicos como indispensáveis para o fortalecimento da própria oposição, e um forte instrumento para chamar novos leitores e assim divulgar as ideias antisalazaristas.

Podemos afirmar que a queda do Estado Novo está extremamente relacionada à queda do colonialismo português na África, e, portanto, não é possível compreender o fím deste regime sem o contexto das guerras. Portugal passava por um processo de reestruturação política e social, as instituições militares que cresceram no conflito viam-se saturadas com as Guerras Coloniais aparentemente sem fim. Entretanto não foi somente o peso das forças internacionais contra o colonialismo de Salazar - depois de 1968 chefiado por Marcello Caetano - que teria provocado a derrocada do colonialismo português. Por parte das colônias 
africanas pode se destacar os grupos de resistência, como a Frente de Libertação de Moçambique (FRELIMO), o Movimento de Libertação da Guiné (MLG) e a Frente Nacional de Libertação de Angola (FNLA), cujas atividades, que iniciaram na década de 60 e não pararam mesmo depois da Revolução dos Cravos, foram decisivas para que as sociedades africanas se tornassem independentes de Portugal. Juntam-se a isto uma complexa rede de apoios de intelectuais e grupos internacionais - entre eles os participantes do Portugal Livre, ou o brasileiro Florestan Fernandes.

A derrubada do Estado Novo era o objetivo final da oposição, contudo a queda de Oliveira Salazar passaria, inevitavelmente pela questão colonialista. A partir daí iniciaram as diversas versões de projetos para a emancipação dos países africanos. Enquanto alguns, como Miguel Urbano Rodrigues e Victor da Cunha Rego, defendiam a imediata libertação daqueles povos, os novos líderes autoproclamados expuseram, cada qual em sua oportunidade, suas próprias intenções para o continente africano. De maneira geral os projetos previam a continuação do vínculo da África com Portugal, pois, a formação nacionalista, e mais abrangente ainda, como império português, passava obrigatoriamente pela pose daqueles países. Isto porque Portugal, segundo os projetos, teria responsabilidade moral e histórica sobre os povos que não saberiam caminhar sozinhos. Em outras palavras os projetos revelavam a própria mentalidade imperialista do Estado Novo, através de dissidentes militares do próprio regime. Mesmo após a carta aberta do edital do jornal afirmando não ser esta a vontade de toda oposição, diversos foram os oposicionistas que puseram sua voz em uníssono com as propostas. Os planos de uma federação portuguesa, com a capital em Angola, foram rechaçados por oposicionistas, intelectuais e estudantes brasileiros e acabou ampliando ainda mais as diferenças entre os oposicionistas, e foi um dos temas que levaria ao encerramento do Portugal Livre.

\section{Referências Bibliográficas}

DAVIDSON, Basil. Questões do Ultramar português. Portugal Livre. Ed. 4: São Paulo, 1960.p.2.

DELGADO, Iva; PACHECO, Carlos; FARIA, Telo (Org.) Humberto Delgado - as eleições de 58. Lisboa: Editora Veja, 1998.

GALVÃO, Henrique. Antropófagos. Porto: Edição Jornal de Notícias, 1947.

GALVÃO, Henrique. África portuguesa de hoje e amanhã. Portugal Livre. São Paulo:1960, p. 5. 
HARRIS, Marvin. O colonialismo Salazarista. Portugal Livre. Ed. 2.São Paulo: 1959, p. 5.

HARRIS, Marvin. A política de Portugal em África II - O indigenato. Portugal Livre Ed. 6. São Paulo:1960, p. 4.

HARRIS, Marvin. A política de Portugal em África III - controle do Indígena. Portugal Livre Ed.7. São Paulo,1960,p. 2.

LOPES, Ana Mônica Henriques. Neocolonialismo na África. Sankofa. Ano IV, No 8, Dezembro de 2011. p. 12.

MENESES, Filipe Ribeiro de. Salazar. Lisboa: Publicações D. Quixote, 2010.

OLIVA, Anderson Ribeiro. De indígena a imigrante: o lugar da África e dos africanos no universo imaginário português dos séculos XIX ao XXI. Sankofa. Revista de História da África e de estudos africanos. N ${ }^{\circ}$. 3, junho de 2009 .

OLIVEIRA, César. “A Evolução Política”. In: Nova História de Portugal, dir. SERRÃO, Joel; MARQUES, A. H. de Oliveira. (dir.). vol. XII, Portugal e o Estado Novo (1930-1960), ROSAS, Fernando (coord)., Lisboa, Presença, 1992

OLIVEIRA, Fabio Ruela. Trajetórias Itelectuais no Exílio: Adolfo Casai Monteiro, Jorge de Sena e Vítor Ramos (1954-194). Rio de Janeiro, Niterói, 2010. (Tese de Doutorado).

PAULO, Heloisa. “Um olhar sobre a Oposição e o Exílio no Portugal de Salazar”. In: Memória das Oposições (1927-1969). Lisboa: Minerva Coimbra, 2010.

PINTO, António Costa. O Estado Novo português e a vaga autoritária dos anos 1930 do século XX. In: O Corporativismo em Português. Estado, Política e sociedade no salazarismo e no varguismo. Rio de Janeiro: Civilização Brasileira, 2007.

RABY, Dawn Linda. A Resistência Antifascista em Portugal. Comunistas, democratas e militares em oposição a Salazar, 1941-1974. Lisboa: Edições Salamandra, 1988.

RODRIGUES, Miguel Urbano. O Tempo e o Espaço em Que Vivi - I - Procurando um Caminho (memórias) Porto: Campo das Letras, 2002.

VALENTIM, Alexandre. A África no imaginário político português. Revista Penélope no. 15. Edições Cosmos, junho de 1995.

SILVA, Douglas Mansur da. A oposição ao Estado Novo no exílio brasileiro: 1956-1974. Lisboa: Imprensa de Ciências Sociais, 2006.

VIDAL, Francisco. Democracia e colonialismo. Portugal Livre Ed. 15. São Paulo: 1961. p. 1.

ZILHÃO, Paulo Manuel Pulido Garcia. Henrique Galvão: prática política e colonial (1926-36). USP, 2006 (Dissertação de mestrado). 